\title{
Extremely rare Turonian belemnites from the Bohemian Cretaceous Basin and their palaeogeographical importance
}

\author{
Martin Košták and Frank Wiese \\ Acta Palaeontologica Polonica 56 (2), 2011: 433-437 doi: http://dx.doi.org/10.4202/app.2010.0004
}

New records of extremely rare late Turonian belemnites are described from the Úpohlavy working quarry in the Bohemian Cretaceous Basin. These specimens are referred to Praeactinocamax bohemicus (Stolley, 1916). An alveolar fragment possibly represents Praeactinocamax strehlensis (Fritsch, 1872) and would be the third find of this species ever recorded. All finds derive from a thin horizon in the uppermost part of the Hudcov limestone (Teplice Formation, uppermost Subprionocyclus neptuni

Ammonite Zone). The small faunule most likely had its origin in a taxon from the Praeactinocamax manitobensis/walkeri/sternbergi group of the North American Province, and its occurrence in Europe can be seen in the context of a southward shift of Boreal taxa in the course of a late Turonian cooling event.

Martin Košták [kostak@natur.cuni.cz], Institute of Geology and Palaeontology, Faculty of Science, Charles University in Prague, Albertov 6, Prague 2, 128 43; Frank Wiese [frwiese@snafu.de], Georg-August-Universität Göttingen, Courant Research Centre Geobiology, Goldschmidtstr. 3, 37077 Göttingen, Germany and FR Paläontologie, Freie Universität Berlin, Malteserstr. 74-100, D-12249 Berlin, Germany.

This is an open-access article distributed under the terms of the Creative Commons Attribution License (for details please see creativecommons.org), which permits unrestricted use, distribution, and reproduction in any medium, provided the original author and source are credited. 